\title{
Article \\ Adult Feeding Preference and Fecundity in the Large Pine Weevil, Hylobius abietis (Coleoptera: Curculionidae)
}

\author{
Petr Doležal ${ }^{1,2, *}$, Lenka Kleinová ${ }^{1,2}$ and Markéta Davídková ${ }^{1} \mathbb{D}$ \\ 1 Biology Centre, Czech Academy of Sciences, Institute of Entomology, \\ 37005 České Budějovice, Czech Republic; lenkaperfollova@email.cz (L.K.); davidkova@entu.cas.cz (M.D.) \\ 2 Faculty of Science, The University of South Bohemia in České Budějovice, \\ 37005 České Budějovice, Czech Republic \\ * Correspondence: dolezal@entu.cas.cz
}

check for

updates

Citation: Doležal, P.; Kleinová, L.; Davídková, M. Adult Feeding Preference and Fecundity in the Large Pine Weevil, Hylobius abietis (Coleoptera: Curculionidae). Insects 2021, 12, 473. https://doi.org/ $10.3390 /$ insects 12050473

Academic Editors: Sandra Vacas and Muhammad Haseeb

Received: 22 April 2021

Accepted: 18 May 2021

Published: 19 May 2021

Publisher's Note: MDPI stays neutral with regard to jurisdictional claims in published maps and institutional affiliations.

Copyright: (c) 2021 by the authors. Licensee MDPI, Basel, Switzerland. This article is an open access article distributed under the terms and conditions of the Creative Commons Attribution (CC BY) license (https:// creativecommons.org/licenses/by/ $4.0 /)$.
Simple Summary: The large pine weevil, Hylobius abietis, is a weevil species that causes extensive damage to coniferous seedlings in Eurasia. Its importance in central Europe has recently increased due to sanitation logging and reforestation activities in the areas of recent bark beetle outbreak. $H$. abietis is a polyphagous species and host plants on which pine weevils develop and feed are important determinants of their fecundity and reproductive success. In this study, we tested adult feeding preferences of $H$. abietis in outdoor conditions, and we studied the influence of food source on fecundity. Seedlings of Pseudotsuga menziesii were the most preferred, but low oviposition indicated lack of nutrients. Feeding on Betula pendula was recorded only in one group of seedlings, and high mortality of weevils was observed. Knowledge of food preferences together with fecundity on alternative food sources may contribute to planning appropriate protective measures and forecasting the damage in areas where former spruce monocultures are being converted to mixed-species stands. Mixed-species plantations could also represent an alternative to insecticidal protection of coniferous seedlings.

Abstract: Adult feeding preferences of Hylobius abietis on Picea abies, Larix decidua, Pinus sylvestris, Pseudotsuga menziesii, Abies alba and Betula pendula were tested in outdoor conditions. The preferred food source was P. menziesii, and the mean bark area consumed per seedling was $440.8 \pm 147.9 \mathrm{~mm}^{2}$. The second most preferred host was $P$. abies. The coniferous species that suffered the least damage was A. alba (76.8 $\pm 62.56 \mathrm{~mm}^{2}$ per seedling). B. pendula was the least preferred source of food, and it caused mortality of $60 \%$ of weevils that fed on it. Weevils exhibited large differences in fecundity when fed with different tree species in a laboratory experiment. The largest number of eggs was laid by females fed with P. abies. Mean egg numbers reached $26.4 \pm 24.89$ eggs per experiment for $P$. abies. Similar fecundity was observed in weevils fed with twigs of $P$. sylvestris. Oviposition was approximately six times lower in females fed with $L$. decidua and P. menziesii. The maximum number of eggs laid by a single female during a one-month experiment was 90 . The results are discussed in relation to management of $H$. abietis.

Keywords: pinaceae; fecundity; seedling damage; forest insects; reproduction

\section{Introduction}

The large pine weevil Hylobius abietis (L.) (Coleoptera: Curculionidae) is an economically important species causing damage in coniferous plantations in Europe and Asia [1,2]. Its pest status is a consequence of modern silvicultural practices that are largely based on clearcuttings and reforestation. Sanitation logging in the areas of recent bark beetle outbreaks in Europe has magnified the amount of available breeding substrate [3-6]. In the Czech Republic, damage by the large pine weevil has doubled every year since 2014 [7] and $H$. abietis was identified as the major threat to successful reforestation in central and northern Europe [8,9]. 
Adult pine weevils fly over long distances in the spring to clear-felled areas to find dying stumps and roots of conifers suitable for breeding [10,11]. When such habitat is found, adults feed on twigs and branches within the crown of fully grown trees in the surroundings. After two or three weeks, weevils lose their ability to fly, and feed on the bark of newly planted or naturally regenerated coniferous seedlings for the rest of the season [12-15]. Feeding typically occurs near the root collar and on the main stem, and damaged seedlings suffer reduced growth or die when the stem is girdled [16,17]. Development of one generation usually lasts one year in central Europe and two years in Scandinavia but can be as long as five years $[2,18]$. Large pine weevil life cycle depends on local conditions and in the absence of obligatory diapause; temperature is the key factor influencing development, voltinism and abundance. In addition, breeding habitats in roots and stumps eliminate the disadvantage of seasonal food availability and to some extent buffer temperature fluctuations, which may lead to continuous development under suitable conditions $[2,9,19,20]$. Shortening of development due to warming climate has recently been recorded in central Europe and emergence of a young generation may occur as early as autumn. Consequently, damage in autumn increases after maturation feeding of young beetles [20-22].

Quality of breeding substrate is another factor that affects both adults and subimaginal stages $[16,23,24]$. H. abietis is a polyphagous species [25-27]. While adults feed on a variety of coniferous and angiosperm trees [2,24], larval development is limited to a few conifer species, among which pine is preferred over spruce [28,29]. Larvae develop faster and suffer lower mortality rates in pines and spruce than in other conifers $[16,30]$. Host plants on which pine weevils developed and feed are important determinants of their fecundity and reproductive success. Generally, hosts favored by adults match those of larvae $[18,23,30]$, but feeding has been documented also on Fraxinus excelsior, Alnus glutinosa, Fagus sylvatica, Quercus robur, Salix spp., Betula spp. and other species of broadleaved trees and shrubs. However, some of the above-mentioned species may lack essential nutrients or contain toxic compounds and their consumption reduces damage on conifers and increases weevil mortality $[27,31]$. From this point of view, establishment of mixed plantings of broad-leaved and coniferous species reduces damages and cost of subsequent protective measures $[22,24,29,31]$.

The objective of this study was to assess the feeding behavior and oviposition rate of $H$. abietis on different plant species. Within this study two experiments were undertaken. The first assessed the adult feeding preferences of $H$. abietis in outdoor conditions when presented with seedlings of five conifer and one broad-leaved species. The second experiment reported here was a laboratory study of the influence of food on fecundity of adults feeding on four species of conifers. The conifers were chosen to reflect the most typical species planted in Central European forestry. Some of these species were tested by previous authors, but for most of them, no studies of $H$. abietis feeding behavior exist. Betula pendula was chosen as a supplementary deciduous tree to verify some controversial results regarding the lethal effect of $B$. pendula to pine weevil $[24,27,31]$. Knowledge on these topics is of high importance for reforestation activities in the areas of recent bark beetle outbreak, where former spruce monocultures are being converted to mixed-species stands. Mixed-species plantations could also represent an alternative to insecticidal protection of coniferous seedlings.

\section{Materials and Methods}

\subsection{Experimental Insects}

Experimental adults were obtained from a laboratory culture maintained on Picea abies roots. After emerging, adult beetles were placed in plastic containers in groups of twenty with a tube of water and fed P. abies and Pinus sylvestris branches. Containers were kept in an insectarium $\left(22^{\circ} \mathrm{C}, 75 \% \mathrm{RH}, \mathrm{LD} 18: 6 \mathrm{~h}\right)$. The weevils used in experiments were ca. 90 days old. 


\subsection{Feeding Preference Experiment}

We tested six species of trees-P. abies, Larix decidua, P. sylvestris, Pseudotsuga menziesii, Abies alba and Betula pendula. The plants used in experiments were one year old seedlings obtained from a commercial nursery (Forests of the Czech Republic, state enterprises, Budkov, Czech Republic). Mean height of seedlings ranged from 25 to $30 \mathrm{~cm}$ and stem diameter above the soil was ca. $0.5 \mathrm{~cm}$. Seedlings were planted in groups of six in big plastic boxes $\left(30 \times 80 \times 50 \mathrm{~cm}^{3}\right.$; height $\times$ length $\times$ width $)$. Groups consisted of one seedling of every tree species mentioned above and in total 5 boxes were made and placed in the shaded place in the garden of the Biology Centre in České Budejovice. Wooden frame covered with polypropylene net was then screwed to each of the boxes and ten weevils were released inside in the summer of 2020. Every week, seedlings were inspected and feeding scars on stems measured with transparent millimeter paper. At the end of the experiment, folded trap bark was placed in each box to collect weevils, and soil was inspected for dead beetles. The experiment lasted 6 weeks.

\subsection{Oviposition Experiment}

In this experiment we tested four species of conifers-P. abies, L. decidua, P. sylvestris and $P$. menziesii. One male and one female $H$. abietis were released in a ventilated clear plastic box. Each box contained a twig of one conifer species (length $100 \mathrm{~mm}$, diameter ca. $15 \mathrm{~mm}$ ) with thin bark serving as a feeding substrate. Prior to the beginning of the experiment beetles were starved for $48 \mathrm{~h}$. A Petri dish with moistened black sand was placed in each box to keep the humidity high and as a substrate for oviposition. In total 40 boxes were prepared, 10 for each tree species. The sex of $H$. abietis was determined according to shape and setae on the last abdominal sternite [32]. The number of laid eggs was recorded at intervals of 2-3 days and twigs replaced with fresh ones. The experiment lasted 28 days.

\subsection{Statistical Analysis}

Data were analyzed in GraphPad v. 6 (GraphPad Software, San Diego, CA, USA). Repeated measures by row ANOVA were used to assess feeding preference and oviposition on different tree species, the repeated measures factor was time. Tukey's multiple comparison test was selected to compare the damages recorded on different seedling species tested.

\section{Results}

\subsection{Feeding Preference Experiment}

The prevalence of feeding by the weevils differed (RM ANOVA, $p<0.0001$ ) among the tree species (Figures 1 and 2). During the first two experimental weeks the preferred food source was $P$. abies. From the third week onwards, weevils started to prefer $P$. menziesii and seedlings of this species sustained the most damage. The mean bark area consumed per seedling was $440.8 \pm 147.9 \mathrm{~mm}^{2}$. The second most preferred host was P. abies $\left(226.8 \pm 72.31 \mathrm{~mm}^{2}\right)$. For nearly the entire experiment, weevils preferred $L$. decidua over $P$. sylvestris. However, damages on $P$. sylvestris dramatically increased during the last week. At the end of experiment mean debarked area reached $181.2 \pm 31.77 \mathrm{~mm}^{2}$ on P. sylvestris and $161.2 \pm 41.10 \mathrm{~mm}^{2}$ on L. decidua. Coniferous species suffering the least damage was $A$. alba. The mean area consumed per seedling was $76.8 \pm 62.56 \mathrm{~mm}^{2}$. B. pendula was the least preferred source of food. Damage was registered only at the last week of experiment in one cage and mean damaged area reached $5.2 \pm 11.63 \mathrm{~mm}^{2}$ (Figures 1 and 2). 


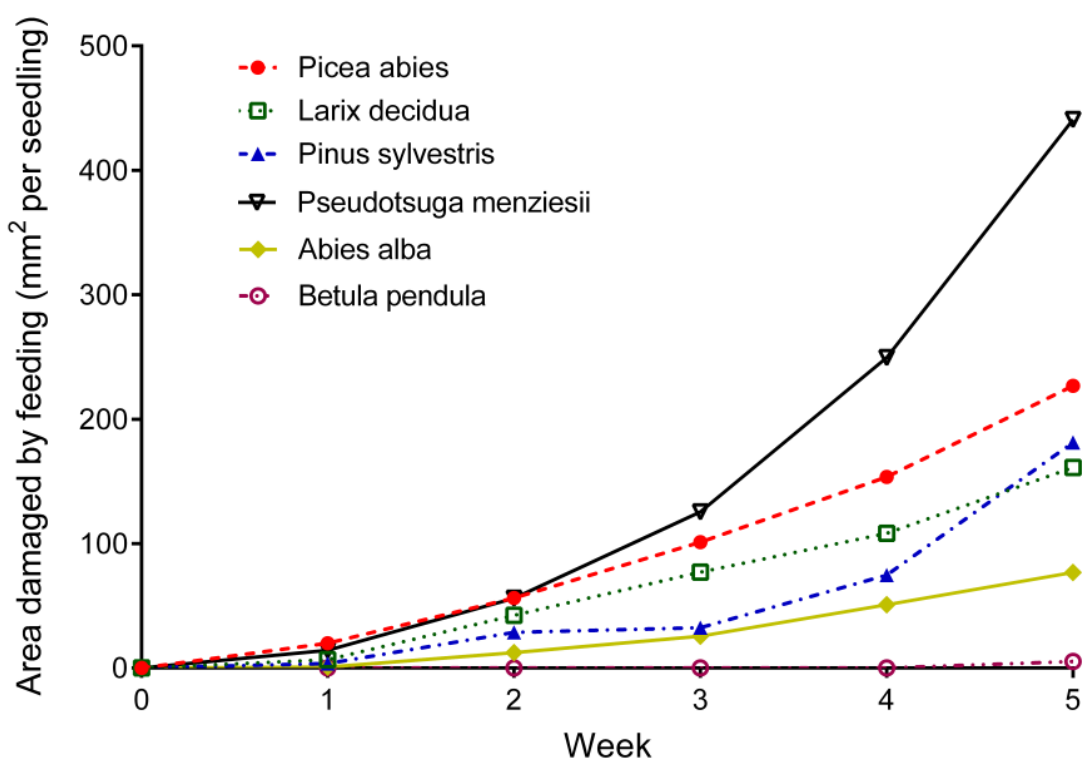

Figure 1. Cumulative mean weekly changes in feeding damage by Hylobius abietis adults on seedlings of 6 different tree species.

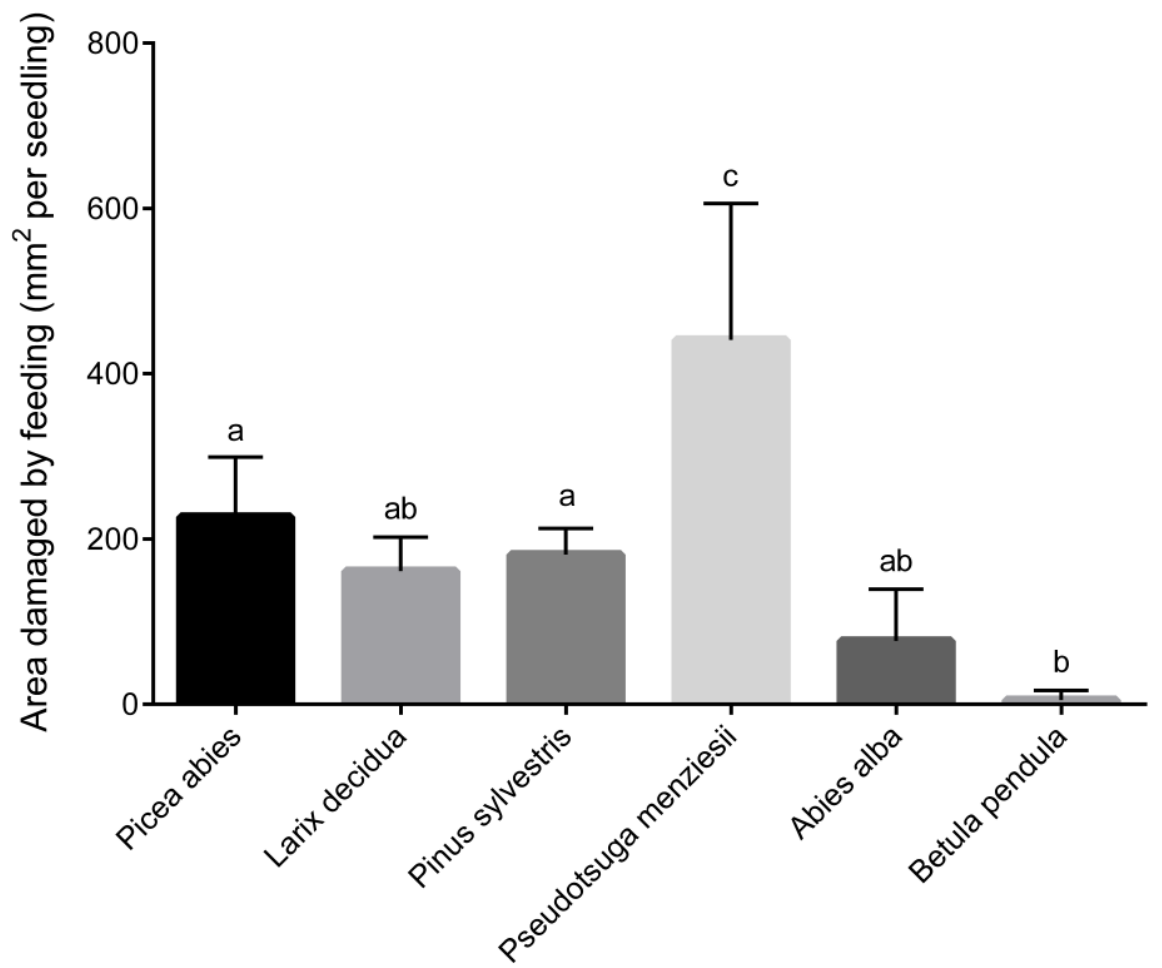

Figure 2. Cumulative mean $( \pm S D$ ) seedling bark surface area consumed at the end of five-weeks experiment on six tree species by Hylobius abietis adults. Different letters above the columns indicate differences $(p<0.05)$ (Tukey's multiple comparison test).

All weevils were found at the end of the feeding experiment. The total mortality rate was $16 \%$. However, mortality varied among boxes. The highest mortality of $60 \%$ was recorded in the box number 5 . In boxes number 2 and 4 mortality reached $10 \%$. No dead weevils were recorded in boxes 1 and 3 . 


\subsection{Oviposition Experiment}

Weevils exhibited large differences in fecundity when fed with different tree species. The largest egg numbers were laid by females fed with P. abies and P. sylvestris. Mean size of egg batches reached $26.4 \pm 24.89$ eggs per female per experiment in the case of $P$. abies. The maximum number of eggs laid by a single female was 90 . Similar fecundity was observed in weevils fed with twigs of P. sylvestris (mean $25.10 \pm 21.66$ eggs per female per experiment, maximum 79 eggs). Females fed with L. decidua and P. menziesii laid less eggs (RM ANOVA, $p=0.0032$ ). Mean size of egg batches per female per experiment was $4.2 \pm 4.64$ and $3.7 \pm 6.55$ for these two tree species, respectively. The maximum number of eggs was 13 in females fed with L. decidua and 21 in females fed with P. menziesii (Figures 3 and 4).

The average egg production during the entire experiment (6 weeks) was almost similar in females fed with P. abies (0.94 eggs per female per day) and P. sylvestris, where average number of eggs per female per day reached 0.89. Six times lower values (RM ANOVA, $p<0.0001$ ) were recorded in L. decidua and P. menziesii, 0.15 and 0.13 eggs per female per day, respectively.

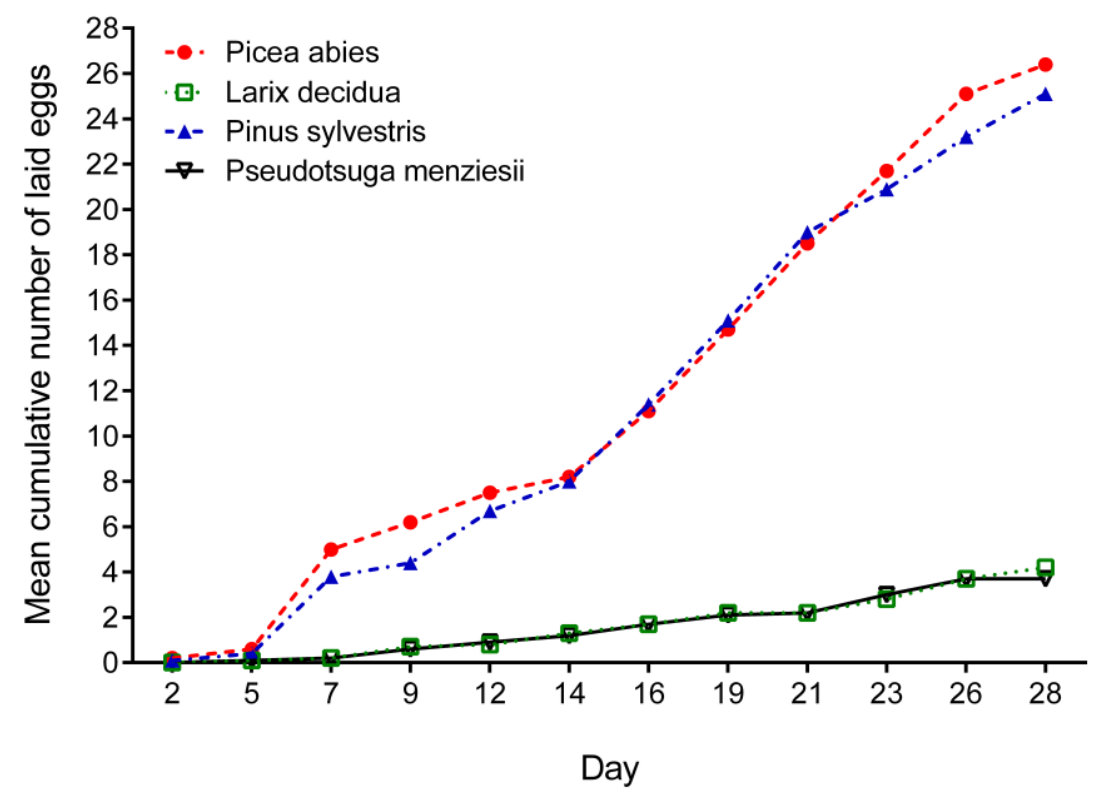

Figure 3. Cumulative number of eggs laid by Hylobius abietis females fed with twigs of different tree species. Graph shows average number of eggs laid by one female. 


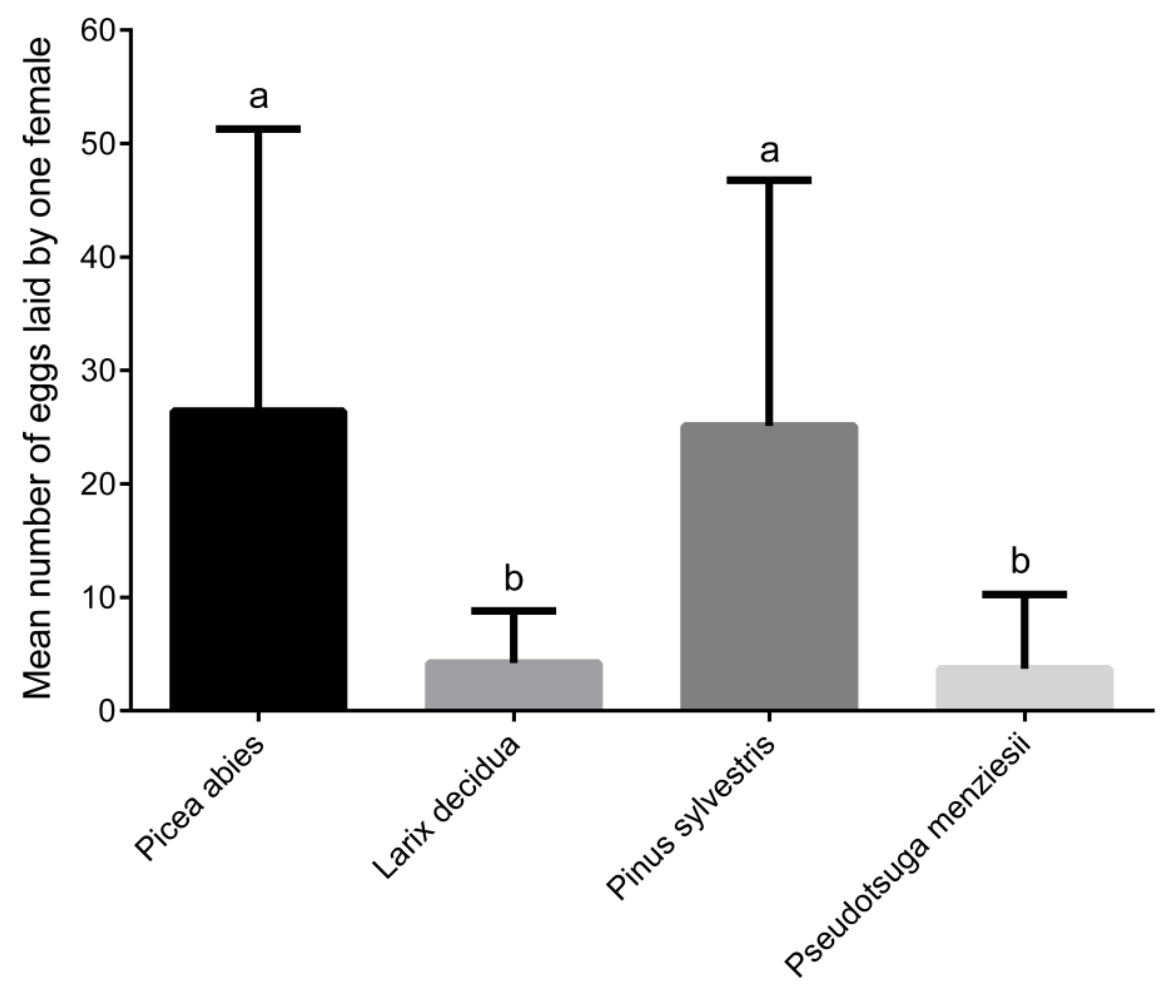

Figure 4. Number of eggs laid by female of Hylobius abietis (mean $\pm \mathrm{SD}$ ) during 28 days experimental period. Different letters above the columns indicate differences $(p<0.05$; RM ANOVA).

\section{Discussion}

Feeding preference experiment results showed conifer tree species are the preferred food source. The largest bark consumption was recorded on P. menziesii. These results are in accordance with $[33,34]$ where in both field and laboratory experiments P. menziesii and Picea sitchensis were the most damaged species. Additionally, relatively high preference for P. abies, P. sylvestris and L. decidua is in agreement with [33]. Similar to our experiment, the only deciduous tree Hybrid aspen (Populus $\times$ wettsteinii) was the least preferred source of food [33]. On the other hand, P. sylvestris seems to be the preferred choice in most previously published feeding behavior studies. P. sylvestris twigs were preferred over those of P. abies in both choice and no choice experiments and weevils consumed twice as much pine bark regardless of temperature regime [29,31]. Results of the present study are contradictory and area of feeding scars on P. abies was double than that of P. sylvestris, which is consistent with [33]. P. menziesii has not been tested in choice experiments by any of the previous authors $[29,31]$ and seedlings of Larix sp. are considered less attractive than P. abies and P. sylvestris $[33,35]$. Feeding on twigs of P. sylvestris, P. abies, B. pendula, Acer pseudoplatanus and F. excelsior was tested in no choice experiment [31]. The most preferred source was $P$. sylvestris, but significant damage was recorded also on B. pendula, which was preferred over $P$. abies [31]. Although $B$. pendula was the second most eaten species, around $70 \%$ of weevils did not feed on it. However, high mortality occurred in beetles that consumed B. pendula [31], which is consistent with the results of the present study. The largest debarked area on $B$. pendula was recorded in the box number 5 , where mortality exceeded $50 \%$. In contrast, less than $10 \%$ of weevils died in other four boxes, where $B$. pendula was not eaten. Previous authors discussed possible effects of thinner bark, lack of nutrients and content of phenolic glycoside compounds as possible explanations for mortality or lower weight gain of weevils feeding on B. pendula $[27,31]$. A. alba was the least preferred conifer host. Although the total area of damaged bark was less than $1 / 6$ of those recorded on P. menziesii, weevils fed on A. alba throughout the whole experiment.

Food source had a significant effect on the number of eggs laid. The highest fecundity was found in females that consumed twigs of P. abies and P. sylvestris. Mean egg batches on 
P. menziesii and L. decidua reached approximately only a fifth of the two above mentioned species. Although P. menziesii was the most damaged host in the feeding preference experiment, oviposition rate indicates its lower nutritional quality, which is consistent with the study [23]. That study reported highest fecundity on P. abies followed by Pinus nigra and P. sylvestris. The size of egg batches on P. menziesii was less than half of those on P. abies. P. sitchensis was the least suitable host with almost $\frac{1}{4}$ of eggs laid. Daily egg production averages in the present study correspond to the $[35,36]$. The reported average number of eggs per female per day was 0.8 in weevils fed with P. sylvestris. Authors of that study [35] estimated the average female in the first year of her life lays 70 eggs per growth season. This is in accordance with results of the present study. The effect of food source on reproductive behavior can be altered by the female age and the time period that given host species was consumed [36]. Besides food source, other key factors influencing number of laid eggs are female age, oviposition site, and temperature during oviposition period [37-39]. Higher oviposition has always been recorded under constant laboratory conditions [37], which may explain the observed maximum numbers of eggs produced by females in our experiments.

The results of current study may have significant implications for reforestation activities in the areas of recent bark beetle outbreak. Among all tested conifer seedlings $P$. menziesii was the most damaged one. Its vulnerability to $H$. abietis feeding should not be neglected since some studies suggest increasing its proportion in newly planted mixtures up to $40 \%$ [40]. Therefore, some kind of seedling protection against $H$. abietis should be applied similarly both to P. abies and P. sylvestris. The results also indicate that some proportion of weevils fed on $B$. pendula even in the presence of coniferous seedlings, which increased their mortality. Planting B. pendula together with conifers may therefore reduce the damage by $\mathrm{H}$. abietis, and thus the need of insecticidal treatment. Knowledge of food preferences together with fecundity on alternative food sources may contribute to planning appropriate protective measures and forecasting the damages in areas, where former spruce monocultures are being converted to mixed-species stands.

Author Contributions: P.D. and M.D. planned the experiments and designed methodology; P.D., L.K. and M.D. collected and analyzed the data; P.D. led the writing of the manuscript. All authors contributed critically to the draft. All authors have read and agreed to the published version of the manuscript.

Funding: This research was funded by Forests of the Czech Republic, state enterprises, grant number 8/2017.

Institutional Review Board Statement: Not applicable.

Data Availability Statement: The data presented in this study are available on request from the corresponding author. The data are not publicly available due to privacy.

Acknowledgments: We would like to thank Ing. Ladislav Půlpán and Ing. Venuše Plchotová (Forests of the Czech Republic) for providing seedlings for food preference experiment, and Pavel Doležal for his assistance in the field. We also thank Robert J. Van Saun for English language corrections and proofreading.

Conflicts of Interest: The authors declare no conflict of interest.

\section{References}

1. Scott, T.M.; King, C.L. The Large Pine Weevil and Black Scots Pine Weevil. U. K. For. Leafl. HMSO Lond. 1974, 58, 1-23.

2. Leather, S.R.; Day, K.R.; Salisbury, A.N. The biology and ecology of the large pine weevil, Hylobius abietis (Coleoptera: Curculionidae): A problem of dispersal? Bull. Entomol. Res. 1999, 89, 3-16. [CrossRef]

3. Jandl, R. Climate-induced challenges of Norway spruce in Northern Austria. Trees For. People 2020, 1, 100008. [CrossRef]

4. Senf, C.; Seidl, R. Mapping the forest disturbance regimes of Europe. Nat. Sustain. 2021, 4, 63-70. [CrossRef]

5. Sommerfeld, A.; Rammer, W.; Heurich, M.; Hilmers, T.; Müller, J.; Seidl, R. Do bark beetle outbreaks amplify or dampen future bark beetle disturbances in Central Europe? J. Ecol. 2021, 109, 737-749. [CrossRef] [PubMed]

6. Hlásny, T.; Zimová, S.; Merganičová, K.; Štěpánek, P.; Modlinger, R.; Turčáni, M. Devastating outbreak of bark beetles in the Czech Republic: Drivers, impacts, and management implications. For. Ecol. Manag. 2021, 490, 119075. [CrossRef] 
7. Lubojacký, J.; Lorenc, F.; Liška, J.; Knížek, M. 2020: Hlavní problémy v ochraně lesa v Česku v roce 2019 a prognóza na rok 2020. In Škodliví Činitelé v Lesích Česka 2019/2020-Krize Zdravotniho Stavu Borovice Lesní. Sborník Referátů z Celostátního Semináře s Mezinárodní Účastí; Lorenc, F., Liška, J., Eds.; Zpravodaj Ochrany Lesa: Průhonice, Czech Republic, 2020; pp. $16-21$.

8. López-Villamor, A.; Carreño, S.; Goldar, X.; Suárez-Vidal, E.; Sampedro, L.; Nordlander, G.; Björklund, N.; Zas, R. Risk of damage by the pine weevil Hylobius abietis in southern Europe: Effects of silvicultural and landscape factors. For. Ecol. Manag. 2019, 444, 2090-2298. [CrossRef]

9. Tudoran, A.; Bylund, H.; Nordlander, G.; Oltean, I.; Puentes, A. Using associational effects of European beech on Norway spruce to mitigate damage by a forest regeneration pest, the pine weevil Hylobius abietis. For. Ecol. Manag. 2021, 486, 118980. [CrossRef]

10. Eidmann, H.H. Assessment of pine weevil numbers on clear-cut and forest sites with shelter boards and pitfall traps. Anz. Schädl. Pflanzenschutz Umweltschutz 1997, 70, 68-72. [CrossRef]

11. Solbreck, C. Dispersal distances of migrating pine weevils, Hylobius abietis, Coleoptera, Curculionidae. Entomol. Exp. Appl. 1980, 28, 123-131. [CrossRef]

12. Långström, B. Abundance and seasonal activity of adult Hylobius weevils in reforestation areas during the first years following final felling. Commun. Instit. For. Fenn. 1982, 106, 1-23.

13. Leather, S.R.; Small, A.A.; Bøgh, S. Seasonal variation in local abundance of adults of the large pine weevil, Hylobius abietis L. (Col.; Curculionidae). J. Appl. Entomol. 1995, 119, 511-513. [CrossRef]

14. Örlander, G.; Nilsson, U.; Nordlander, G. Pine weevil abundance on clear-cuttings of different ages: A 6-year study using pitfall traps. Scand. J. For. Res. 1997, 12, 225-240. [CrossRef]

15. Örlander, G.; Nordlander, G.; Wallertz, K.; Nordenhem, H. Feeding in the Crowns of Scots Pine Trees by the Pine Weevil Hylobius abietis. Scand. J. For. Res. 2000, 15, 194-201. [CrossRef]

16. Thorpe, K.V.; Day, K.R. The impact of host plant species on the larval development of the large pine weevil Hylobius abietis L. Agric. For. Entomol. 2002, 4, 187-194. [CrossRef]

17. Day, K.R.; Nordlander, G.; Kenis, M.; Halldorson, G. General Biology and Life Cycles of Bark Weevils. In Bark and Wood Boring Insects in Living Trees in Europe, a Synthesis; Lieutier, F., Day, K.R., Battisti, A., Grégoire, J.C., Evans, H.F., Eds.; Springer: Dordrecht, Germany, 2004; pp. 331-349. [CrossRef]

18. Beyer-Petersen, B.; Juutinen, B.; Kangas, P.; Bakke, E.; Butovitsch, A.; Eidmann, M. Studies on Hylobius abietis L. I. Development and life cycle in the Nordic countries. Anz. Schadl. 1964, 37, 14-15. [CrossRef]

19. Moore, R.; Brixey, J.M.; Milner, A.D. Effect of time of year on the development of immature stages of the Large Pine Weevil (Hylobius abietis L.) in stumps of Sitka spruce (Picea sitchensis Carr.) and influence of felling date on their growth, density and distribution. J. Appl. Entomol. 2004, 128, 167-176. [CrossRef]

20. Wainhouse, D.; Inward, D.J.G.; Morgan, G. Modelling geographical variation in voltinism of Hylobius abietis under climate change and implications for management. Agric. For. Entomol. 2014, 16, 136-146. [CrossRef]

21. Inward, D.J.G.; Wainhouse, D.; Peace, A. The effect of temperature on the development and life cycle regulation of the pine weevil Hylobius abietis and the potential impacts of climate change. Agric. For. Entomol. 2012, 14, 348-357. [CrossRef]

22. Lalík, M.; Galko, J.; Nikolov, C.; Rell, S.; Kunca, A.; Modlinger, R.; Holuša, J. Non-pesticide alternatives for reducing feeding damage caused by the large pine weevil (Hylobius abietis L.). Ann. Appl. Biol. 2020, 177, 132-142. [CrossRef]

23. Wainhouse, D.; Ashburner, R.; Boswell, R. Reproductive development and maternal effects in the pine weevil Hylobius abietis. Ecol. Entomol. 2001, 26, 655-661. [CrossRef]

24. Månsson, E.; Schlyter, F. Hylobius pine weevils adult host selection and antifeedants: Feeding behaviour on host and non-host woody scandinavian plants. Agric. For. Entomol. 2004, 6, 165-171. [CrossRef]

25. Sylvén, H. Snytbaggarna. Skogsvårdsföreningens Tidskrift. 1927, 3, 521-555. (In Swedish)

26. Örlander, G.; Nordlander, G.; Wallertz, K. Extra Food Supply Decreases Damage by the Pine Weevil Hylobius abietis. Scand. J. For. Res. 2001, 16, 450-454. [CrossRef]

27. Toivonen, R.; Viiri, H. Adult large pine weevils Hylobius abietis feed on silver birch Betula pendula even in the presence of conifer seedlings. Agric. For. Entomol. 2006, 8, 121-128. [CrossRef]

28. Munro, J.W. The biology and control of Hylobius abietis, L. Int. J. For. Res. 1928, 2, 31-39. [CrossRef]

29. Leather, S.R.; Ahmed, S.I.; Hogan, L. Adult feeding preferences of the large pine weevil, Hylobius abietis (Coleoptera: Curculionidae). EJE 1994, 91, 385-389.

30. Guslits, I.S. Vlijanie uslovij pitanija plodovitost' I ziznedejetal'nost' zukov bol'sogo sosnovogo dolgonosika-Hylobius abietis L. Zool. Zhurnal 1970, 49, 862-868.

31. Manlove, J.D.; Styles, J.; Leather, S.R. Feeding of the adults of the large pine weevil, Hylobius abietis (Coleoptera: Curculionidae). EJE 1997, 94, 153-156.

32. Öhrn, P.; Klingenberg, M.; Hopkins, G.; Björklund, N. Two non-destructive techniques for determining the sex of live adult Hylobius warreni. Can. Entomol. 2008, 140, 617-620. [CrossRef]

33. Wallertz, K.; Nordenhem, H.; Nordlander, G. Damage by the pine weevil Hylobius abietis to seedlings of two native and five introduced tree species in Sweden. Silva Fenn. 2014, 48, 1-14. [CrossRef]

34. Novák, J.; Dušek, D.; Kacálek, D. Růst kultur douglasky ve směsi s domácími dřevinami na různých lesních stanovištích. [Growth of juvenile Douglas-fir mixed with native tree species on different forest sites]. Zprávy Lesnického Výzkumu 2019, 64, 133-139. 
35. Löf, M.; Isacsson, G.; Rydberg, D.; Welander, T.N. Herbivory by the pine weevil (Hylobius abietis L.) and short-snouted weevils (Strophosoma melanogrammum Forst. and Otiorhynchus scaber L.) during the conversion of a wind-thrown Norway spruce forest into a mixed-species plantation. For. Ecol. Manag. 2004, 190, 281-290. [CrossRef]

36. Thorpe, K.; Day, K. Reproductive maturation in the large pine weevil Hylobius abietis: The relative importance of larval and adult diet. Agric. For. Entomol. 2008, 10, 53-59. [CrossRef]

37. Bylund, H.; Nordlander, G.; Nordenhem, H. Feeding and oviposition rates in the pine weevil Hylobius abietis (Coleoptera: Curculionidae). Bull. Entomol. Res. 2004, 94, 307-313. [CrossRef] [PubMed]

38. Nordlander, G.; Nordenhem, H.; Bylund, H. Oviposition patterns of the pine weevil Hylobius abietis. Entomol. Exp. Appl. 1977, 85, 1-9. [CrossRef]

39. Hopkins, G.R.; Klingenberg, M.D.; Aukema, B.H. Temptations of weevil: Feeding and ovipositional behaviour of Hylobius warreni Wood on host and nonhost bark in laboratory bioassays. Agric. For. Entomol. 2009, 11, 397-403. [CrossRef]

40. Neuner, S.; Beinhofer, B.; Knoke, T. The optimal tree species composition for a private forest enterprise-Applying the theory of portfolio selection. Scand. J. For. Res. 2013, 28, 38-48. [CrossRef] 